\title{
EFFECTS OF GINGER JUICE ON BLOOD GLUCOSE IN ALLOXAN INDUCED DIABETES MELLITUS IN RATS
}

\author{
SULTANA $\mathrm{S}^{1}$, KHAN MI ${ }^{2}$, RAHMAN H ${ }^{3}$, NURUNNABI ASM ${ }^{4}$, AFROZ RD $^{5}$

\begin{abstract}
Objective: To find out the effects of ginger (Zingiber officinale) juice blood glucose in alloxan
\end{abstract} \\ induced-diabetes mellitus in rats. \\ Methods: This experimental study was done in the Department of Pharmacology \& \\ Therapeutics, Dhaka Medical College, Dhaka, in collaboration with the Departments of Pathology, \\ Ibrahim Medical College, Dhaka between January and December 2009. This experimental \\ animal study was divided into two parts, which were Experiment-1 and Experiment-2. \\ Experiment 1 comprises of 12 rats and divided into 2 groups each group having 6 rats. Rats of \\ group-A was non-diabetic normal control group and group-B was fed with ginger (Zingiber \\ officinale) in a dose of $4 \mathrm{ml} / \mathrm{kg}$ body weight orally through Ryle's tube. Experiment-2 comprised \\ of 12 rats divided into 2 groups each containing 6 rats labeled as group C, group D. Rats of \\ groups $C$ administered alloxan $150 \mathrm{mg} / \mathrm{kg}$ intraperitoneally on the 2nd day of the study. Rats \\ of group D were administered alloxan $150 \mathrm{mg} / \mathrm{kg}$ intraperitoneally and ginger $(4 \mathrm{ml} / \mathrm{kg}$ of body \\ weight orally) on the 2nd day of the study. \\ Results: The fasting blood glucose level at day 12 in the rats treated with ginger (Zingiber \\ officinale) $4 \mathrm{ml} / \mathrm{kg}$ body weight orally daily for 12 days showed reduction in fasting blood \\ glucose level as compared to control group, but not significant, which indicates that ginger has \\ no effect in lowering blood glucose of normal rats. The fasting blood glucose levels at day 12 in \\ the rats of group $D$ (treated with ginger and alloxan) showed highly significant reduction in \\ fasting blood glucose level as compared to diabetic control group $(p<0.002)$.
}

Conclusion: Consumption of ginger produced a significant antihyperglycemic effect in experimentally induced diabetic rats.

Key words: Ginger, blood glucose, alloxan, diabetis mellitus, rats.

J Dhaka Med Coll. 2014; 23(1) : 14-17.

\section{Introduction:}

Diabetes mellitus is one of the most common endocrine disorders affecting almost $6 \%$ of the world's population. The prevalence of diabetes for all age-groups worldwide was estimated to be $2.8 \%$ in 2000 and $4.4 \%$ in 2030. The total number of people with diabetes is projected to rise from 171 million in 2000 to 366 million in $2030^{1}$. The Incidence and prevalence of diabetes mellitus are increasing worldwide, in line with lifestyle changes and population aging. Herbal remedies have been used in medical practices for many years in East Asian countries and account for approximately $80 \%$ of medical treatments in the developing countries ${ }^{2}$. Therefore, herbal medicine is growing popularity in western country and become more and more important in people healthcare. In recent years, ginger has become a subject of interest because of its beneficial effects on human health. Ginger has a broad range of biological activities including anti-bacterial, anti-convulsant,

1. Dr. Selima Sultana, Assistant Professor, Department of Pharmacology \& Therapeutics, Ad-Din Women's Medical College, Dhaka.

2. Prof. Md. Ismail Khan, Professor \& Head, Department of Pharmacology \& Therapeutics, Dhaka Medical College, Dhaka.

3. Dr. Hasanur Rahman, Assistant Professor, Department of Pharmacology \& Therapeutics, Dhaka Medical College, Dhaka.

4. Dr. Abu Sadat Mohammad Nurunnabi, Assistant Professor, Department of Anatomy, OSD, Directorate General of Health Services (DGHS), Dhaka.

5. Dr. Rokhsana Dil Afroz, Assistant Professor, Department of Pharmacology \& Therapeutics, Shaheed Suhrawardy Medical College, Dhaka.

For correspondence: Dr. Selima Sultana, Assistant Professor, Pharmacology, Ad-Din Women's Medical College, Dhaka. Cell No: 01199552144. E-mail: ark_udd@ yahoo.com 
analgesic, anti-ulcer, and anti-fungal ${ }^{2,3}$. There is also evidence that ginger may help in the treatment of cardiovascular disease due its anti-infiammatory, anti-platelet and hypolipidemic effects ${ }^{4}$. Researchers reported that the inorganic part of a medicinal plant contains mainly mineral elements, which are responsible for the hypoglycemic activity. In support of this view, a number of essential minerals $\left(\mathrm{Ca}^{++}, \mathrm{Zn}^{++}, \mathrm{K}^{+}\right.$etc.) are known to be associated with the mechanism of insulin release and its activity in different animals $\&$ human beings ${ }^{5,6,7}$. The present study was designed to see the effects of ginger (Zingiber officinale) extract on blood glucose in alloxan induced diabetes mellitus in rats.

\section{Methods:}

This experimental study was done in the Department of Pharmacology \& Therapeutics, Dhaka Medical College, Dhaka, in collaboration with the Department of Pathology, Ibrahim Medical College, Dhaka, and the Department of Chemistry, University of Dhaka, from January to December of 2009.

Animals: Male Wistar rats weighing 130-150 gm obtained from Bangabandhu Sheikh Mujib Medical University (BSMMU), Dhaka. The rats were housed in polycarbonate cages at a regulated temperature of $22^{\circ} \mathrm{C}$ and humidity of $55.0 \%$ controlled room with a $12 \mathrm{~h}$ light $/ 12 \mathrm{~h}$ dark cycle. The rats were fed on standard pellets of rat diet and allowed to drink water ad libitum.

Plant materials and ginger extraction: The fresh rhizomes of ginger (Zingiber officinale) obtained from local market and ginger juice was prepared using the method of Akhani et al. ${ }^{8}$. Fresh rhizomes of ginger $(1 \mathrm{~kg})$ were crushed and then squeezed in muslin cloth to obtain the juice, which was stored in the refrigerator at $2-8^{\circ} \mathrm{C}$ centigrade in a well closed glass container.

This experimental animal study was divided into two parts, which were Experiment-1 and Experiment-2.
The experiments were designed to demonstrate the effect of ginger on blood glucose in nondiabetic and alloxan induced diabetes mellitus in rats. Body weight of all rats was recorded.

Experiment-1: This experiment comprises of 12 rats. Rats were divided into 2 groups each group having 6 rats. Groups were labeled as group-A and group-B. This part of the experiment was carried out to demonstrate, the effect of ginger extract on blood glucose of non-diabetic normal and ginger treated rats. Blood glucose was estimated on day 12.

Group-A: This group served as non-diabetic normal control group. The rats were treated with normal rat fed and water ad libitum for 11 days.

Group-B: The rats of this group were given ginger in a dose of $4 \mathrm{ml} / \mathrm{kg}$ body weight orally through ryles tube from the 2 nd day to 11 th day along with normal rat fed and water.

On 12 th day, fasting blood glucose was estimated.

Experiment-2: Comprised of total 12 rats and they were divided into 2 groups each containing 6 rats labeled as group C \& group D.

Group-C: On the 1st day, fasting blood glucose and body weight of this group were estimated. Rats were administered alloxan $150 \mathrm{mg} / \mathrm{kg}$ intraperitoneally on the 2 nd day of the study and after 3 days (72 hours) i.e. on the 5 th day, blood glucose was estimated again (since alloxan increases blood glucose after 72 hours) and rats with blood glucose of $>7 \mathrm{mmol} / \mathrm{L}$ were considered dialectic $\&$ selected for experiment and given standard rat fed and water for next 6 days and on the 12th day blood glucose was estimated.

Group-D: Rats of this group were administered alloxan $150 \mathrm{mg} / \mathrm{kg}$ intraperitoneally and ginger $(4 \mathrm{ml} / \mathrm{kg}$ of body weight orally) on the 2 nd day of the study and after 3 days (72 hours) blood glucose level estimated and ginger extract along with rat fed and water were continued for next 6 days and on the 12th day, blood glucose and body weight were estimated.

All the rats were sacrificed on 12 th day by an overdose of diethyl ether, after measuring 
fasting blood glucose. Blood glucose was measured by using a glucometer ('ACCU-CHEK', made by Roche Diagnostic GmbH, D-68298, Mannheim, Germany) and expressed as mmol/ L.

Statistical analysis: The results were presented in tables and figures. Unpaired Student's t-test was performed. Level of significance was expressed as $\mathrm{P}$ value. $\mathrm{P}$ value of $<0.05$ was considered as significant.

\section{Results:}

At day 1 and day 12 mean fasting blood glucose level of group A were $5.40 \pm 0.76$ and $5.45 \pm 0.76$ $\mathrm{mmol} / \mathrm{L}$ respectively. Percentage of improvement from day 1 to day 12 was $1.02 \pm 3.88$. In group $B$, the mean fasting blood glucose level at day 1 and day 12 were $5.67 \pm 0.57$ and $5.47 \pm 0.59 \mathrm{mmol} / \mathrm{L}$ respectively. Percentage of reduction from day 1 to day 12 was $-3.38 \pm 7.06$. The fasting blood glucose level at day 12, the rats treated with ginger extract $4 \mathrm{ml} / \mathrm{kg}$ body weight orally daily for 12 days showed a small but not significant reduction in fasting blood glucose level as compared to control group. Hence, it can be concluded that ginger has no effect in lowering blood glucose of normal rats.
In group $\mathrm{C}$, the mean blood glucose level at day 1 , day 5 and day 12 were $5.57 \pm 0.12,9.20 \pm 0.76$ and $8.52 \pm 0.68 \mathrm{mmol} / \mathrm{L}$ respectively. Percentage of improvement from day 1 to day 12 was $52.92 \pm 10.67$. In group D, the mean blood glucose level at day 1 , day 5 and day 12 were $5.63 \pm 0.46$, $7.92 \pm 0.48,7.13 \pm 0.42 \mathrm{mmol} / \mathrm{L}$ respectively. Percentage of improvement from day 1 to day 12 was $27.34 \pm 13.02$. In group $\mathrm{E}$, the mean blood glucose level at day 1 and day 12 were $5.73 \pm 0.56$, $7.50 \pm 0.42 \mathrm{mmol} / \mathrm{L}$ respectively. Percentage of improvement from day 1 to day 12 was $31.59 \pm 12.00$. The fasting blood glucose levels at day 12 in the rats of group D showed highly significant reduction in fasting blood glucose level as compared to diabetic control group $(p<0.002)$. Therefore, it can be concluded that ginger has effect in lowering blood glucose of diabetic rats. The fasting blood glucose level of the rats of group $\mathrm{E}$ showed significant reduction of fasting blood glucose level as compared to diabetic control group $(\mathrm{p}<0.01)$. Hence, it can be concluded that ginger extract has preventive role in lowering blood glucose of diabetic rats.

The results are shown in Table-I.

Table I

Effects of ginger extract and alloxan on blood glucose level of the different rats group at 1st day and 12 th day

\begin{tabular}{lccl}
\hline Fasting blood glucose $(\mathrm{mmol} / \mathrm{L})$ & Group A & Group B & P value \\
\hline At $1^{\text {st }}$ day & $5.40 \pm 0.76$ & $5.67 \pm 0.57$ & $0.509^{\mathrm{ns}}$ \\
At $12^{\text {th }}$ day & $5.45 \pm 0.76$ & $5.47 \pm 0.59$ & $0.967^{\mathrm{ns}}$ \\
Percentage of improvement from & $1.02 \pm 3.88$ & $-3.38 \pm 7.06$ & $0.211^{\mathrm{ns}}$
\end{tabular}

day 1 to day 12

\begin{tabular}{lccl}
\hline Fasting blood glucose $(\mathrm{mmol} / \mathrm{L})$ & Group C & Group D & P value \\
\hline At $1^{\text {st }}$ day & $5.57 \pm 0.12$ & $5.63 \pm 0.46$ & $0.740^{\text {ns }}$ \\
At $5^{\text {th }}$ day & $9.20 \pm 0.76$ & $7.92 \pm 0.48$ & $0.006^{* *}$ \\
At $12^{\text {th }}$ day & $8.52 \pm 0.68$ & $7.13 \pm 0.42$ & $0.002^{* *}$ \\
Percent of improvement from & $52.92 \pm 10.67$ & $27.34 \pm 13.02$ & $0.004^{* *}$ \\
day 1 to day 12 & & & \\
\hline
\end{tabular}

Here, data were expressed as mean $\pm \mathrm{SD}$; comparisons were done by using unpaired Student's ' $\mathrm{t}$ ' test; ${ }^{* * *}=$ Significant, $\mathrm{ns}=$ Not significant. 


\section{Discussion:}

The present study was carried out to evaluate the effects of ginger extract on blood glucose in alloxan induced diabetes mellitus in rats. Its blood glucose lowering effect was tested in normal and experimentally induced diabetic rats. The fresh juice of ginger was given for 10 consecutive days in both normal and alloxaninduced diabetic rats.

In the present study, diabetes was induced by alloxan. The dose and route of administration of alloxan was $(150 \mathrm{mg} / \mathrm{kg}$ of body weight) intraperitonially, which produced significant increase in blood glucose in this study. In this study persistant hyperglycemia was observed 72 hours following administration of alloxan in a dose of $150 \mathrm{mg} / \mathrm{kg}$ intraperitonially. In this study, the antihyperglycemic effect of ginger was demonstrated in alloxan induced diabetic rats. The doses of ginger used in this study were selected in keeping conformity with the dose used in different research work ${ }^{7}$. In experimental group, there was statistically significant changes $(p<0.002)$ in the mean fasting blood glucose level of rats treated with ginger $4 \mathrm{ml} / \mathrm{kg}$ body weight. Therefore, it may be concluded that ginger has antihyperglycemic action in experimentally induced diabetic rats. The present findings are in agreement with those previous works that are cited here. In this study pretreatment with ginger followed by induction of diabetes decreased significantly the mean fasting blood glucose when compared with the diabetic group. The results comply with the previously reported work of Akhani et al. ${ }^{8}$ as they reported that ginger pretreatment inhibited the induced hyperglycemia and hypoinsulinaemia. Majeed et al. ${ }^{9}$ and Jafri et al. ${ }^{10}$ also found the hypoglycemic effects of ginger in their experiments on rats. They found that posttreatment and pretreatment of streptozotocininduced diabetic rats with ginger extract significantly decreased the blood glucose level and increased the insulin level.
In this study, it was observed that ginger has antihyperglycemic effect in Alloxan induced diabetic rats. The results suggested that ginger may be a useful agent in the treatment and prevention of diabetes mellitus. To validate this finding, further studies with toxicological testing are recommended ${ }^{7,10}$.

\section{Conclusion:}

It could be concluded that ginger (Zingiber officinale) extract has antihyperglycemic effect in experimentally induced diabetic rats.

\section{References:}

1. Kumar A, Mohan U, Jain VC. Influence of some socio-demographic factors on smoking status of academicians. Ind $\mathrm{J}$ Chest Dis Allied Sci 1997; 39(1): 5-12.

2. Ahmed RS, Sharma SB. Biological studies on combined effects of garlic (Allium sativum Linn.) and ginger (Zingiber officinale Roscoe.) in albino rats. J Exp Biol 1997; 35: 841-3.

3. Kikuzaki H, Nakatani N. Antioxidant effects of ginger constituents. J Food Sci 1993; 58: 1407-10.

4. Nicoll R, Henein MY. Ginger (Zingiber officinale Roscoe): a hot remedy for cardiovascular disease? Int J Cardiol 2009; 131(3): 408-9.

5. Marles RJ, Farnsworth NR. Antidiabetic plants and their active constituents. Phytomedicine 1995; 2(2): 137-89.

6. Ajit K, Choudhary BK, Bandhopadhyay NG. Preliminary studies on the inorganic constituents of some indigenous hypoglycemic herbs on oral glucose tolerance test. J Ethnopharmacol 1999; 64: 179-84.

7. Sharma M, Shukla S. Hypoglycaemic effect of ginger. J Res Ind Med Yoga Homoeopathy 1977; 12: 127-30.

8. Akhani SP, Vishwakarma SL, Goyal RK. Antidiabetic activity of Zingiber officinale in Streptozotocin-induced type I diabetic rats. J Pharm Pharmacol 2004; 56: 101-5.

9. Majeed AA, Martha T, Khaled K, Tariq M, Muslim A. Biochemical and histopathological toxicity of aqueous ginger extract in female rats. Kuwait $\mathrm{J}$ Sci Eng 2003; 30: 35-48.

10. Jafri SA, S Abass, Qasim M. Hypoglycemic effect of ginger (Zingiber officinale) in Alloxan induced diabetic rats (Rattus norvagicus). Pak Vet J 2011; 31(2): 160-2. 